\title{
THE INFLUENCE OF HEAVY METALS ON THE BIOLOGICAL ACTIVITY OF RETISOLS
}

Tatyana GUSEVA, Federal State Budgetary Educational Institution of Higher Education Ryazan State Medical University n. I.P. Pavlova, 9 Vysokovoltnaya str., 390026, Ryazan, Russia, guseva.tm@yandex.ru (corresponding author)

Yuri MAZHAISKY, Meshchersky Branch of the All-Russian Scientific Research Institute of Hydraulic Engineering and land reclamation n. A.N. Kostyakova, 1A Meshcherskaya str., 390021, Ryazan, Russia, director@mntc.pro

Veronica VCHERASHNYAYA, Belarusian State Order of the October Revolution and the Red Banner of Labor Agricultural Academy, Michurina str., 5213410, Gorki, Belarus, felixcat2021@mail.ru

\begin{abstract}
Environmental problems have not lost their relevance for the Non-Chernozem zone of Russia, the southern part of which belong to the Ryazan region, where in a number of areas there is a critical situation of cultural landscapes contamination of with heavy metals. The aim of the research was to assess the influence of multi-level heavy metal contamination of Retisols for the parameters of its phytotoxicity and the activity of soil enzymes. In the model experiment on Retisols, it was shown that the complex effect of heavy metals that are priority for the Ryazan region such as copper, zinc, lead, cadmium, at doses of 1.5 and 3.5 UEC (approximate permissible concentration) reduces the activity of soil enzymes and has a toxic effect on the cereal-legume mixture. In the variant of the experiment with heavy metal content of 0.5 UEC in the soil, the studied elements, mainly zinc and copper, act as chemical meliorants for Retisols depleted with trace elements. The combined effect of heavy metals $(\mathrm{Cu}, \mathrm{Zn}, \mathrm{Pb}, \mathrm{Cd})$ in doses of 1.5 and 4.5 UEC is phytotoxic what negatively affects the biometric indicators of the cereal-bean mixture, and also leads to accumulation in the biomass in quantities exceeding the permissible standards.
\end{abstract}

Keywords: heavy metals, Retisols, cereal-bean mixture, model experiment, phytotoxicity, soil enzymes.

\section{INTRODUCTION}

In modern conditions, the processes of technogenic pressure on agroecosystems are becoming more significant, and their scale is more intense. All components of cultural landscapes are under constant anthropogenic pressure. The state of soil in agricultural landscapes requires special attention, since the influence of technogenesis leads to a change in their agrochemical and physical properties, as well as microbiological and biochemical parameters, that deprives the soil cover of the ability to perform ecological functions (Mazhaisky et al., 2003). Soil microbiome and soil biochemical parameters are most sensitive to pollution. Technogenesis, in particular heavy metals (HM), changes the species composition and abundance of microbiota, suppresses respiration processes, inhibits the activity of soil enzymes such as catalase, invertase, amylase, and others (Ananyeva et al., 2010; Korotchenko, 2011). As a result, the soil loses its fertility, the ability to effectively carry out the biological cycle, and maintain homeostasis. For this reason, these indicators are considered the most objective indicators of the state of the soil cover (Evdokimova et al., 2017). Enzymatic activity is the most variable soil characteristic, which is sensitive to the occurrence of a stress situation in the soil (Kurakov, 2000; Evdokimova, 2014; Mazhaisky et al., 2014; Fokina et. al., 2015; Skugoreva et al., 2016).

For many years, environmental problems have not lost their relevance for the Nonchernozem zone of the Russian Federation, to the southern part of which the Ryazan region belongs, where in a number of regions there is a critical situation in the pollution of cultural landscapes by heavy metals. Research carried out on the territory of the region revealed a priority range of HMs - the main soil pollutants. A significant amount of information has been accumulated on the effect of pollutants on the agrochemical and agrophysical properties of the soil, the quality of crop production, but the aspects related to the biological activity of the soil, which can provide operation al data on the negative effect of toxic elements, have not been sufficiently studied (Neutralization of contaminated soil..., 2008). The aim of the research was to assess the influence of the level of heavy metal pollution in Retisols on the parameters of its phytotoxicity and the activity of soil enzymes.

Copyright (C) 2021 The Authors. Published by Vytautas Magnus University. This is an open-access article distributed under the terms of the Creative Commons Attribution License (CC BY 4.0), which permits unrestricted use, distribution, and reproduction in any medium, provided the original author and source are credited. 


\section{MATERIALS AND METHODS}

The research was carried out on the territory of the Ryazan region, located within the Meshcherskaya lowland of the southern part of the Non-Chernozem zone of Russia at the experimental site of the All-Russian Research Institute of Hydraulic Engineering and Land Reclamation under the conditions of a model experiment using vegetation vessels. Retisolsl and oat-pea mixture were selected as objects of the research. The soils used in the experiment had the following agrophysical and agrochemical characteristics (for a layer of 0-40 cm): volume mass $-1.27 \mathrm{~g} / \mathrm{cm}^{3}$, solid phase density $-2.59 \mathrm{~g} / \mathrm{cm}^{3}, \mathrm{pH}-6.3$, mobile phosphorus content $-29.0 \mathrm{mg} / 100 \mathrm{~g}$ of soil, exchangeable potassium $19.4 \mathrm{mg} / 100 \mathrm{~g}$ of soil. Heavy metals - copper, zinc, lead and cadmium, selected on the basis of the priority of pollutants in the agricultural landscapes of the Ryazan region, were introduced into the upper soil layer in the form of readily soluble salts $\left(\mathrm{CuSO}_{4} \cdot 5 \mathrm{H}_{2} \mathrm{O}, \mathrm{ZnSO}_{4} \cdot 7 \mathrm{H}_{2} \mathrm{O}, \mathrm{Pb}\left(\mathrm{CH}_{3} \mathrm{COO}\right)_{2} \cdot 3 \mathrm{H}_{2} \mathrm{O}, \mathrm{CdSO}_{4}\right)$, in concentrations based on the total pollution index $(\mathrm{Zc})$, in order to cover pollution from acceptable to extremely hazardous (Methodical instructions..., 1999). With the combined introduction of copper, zinc, lead and cadmium into the soil at a concentration of 0.5 of the approximate permissible concentration (APC), the permissible category of pollution was modeled (variant 1), 1.5 APC - moderately hazardous (variant 2), 4.5 APC - extremely dangerous (variant 3) (Approximately permissible..., 2006). As a control in the experiment, we used a Retisols with a background content of HM, which according to Zc was characterized as unpolluted. The experiment was carried out in 4-fold repetition. In the experiment, vegetative vessels with an area of $500 \mathrm{~cm}^{2}$ were used, which were installed in an open area. The experiment was conducted for 2 months. The biometric observations were carried out on plants during the experiment. All grown plants were evaluated according to such indicators as the height and diameter of the leaf plate. In order to assess the safety and environmental cleanliness, at the end of the experiment, the accumulating capacity of the pea-cereal mixture was determined by atomic absorption spectrometry on an AAS-1 spectrophotometer. Before harvesting, an soil samples from all vegetation vessel in order to determine the enzymatic activity. In the experiment, the activity of hydrolytic enzymes that form the nutrient regime of the soil was determined: invertase, urease and phosphatase. Invertase catalyzes the reactions of hydrolytic decomposition of sucrose with the formation of fructose molecules - an energy product for microorganisms, the activity of this enzyme reflects the level of fertility and biological activity of soil. Urease catalyzes the hydrolytic decomposition of urea into ammonia and carbon dioxide. Phosphatase catalyzes the hydrolysis of a number of organophosphorus compounds. The analysis of the enzyme activity was carried out by the methods accepted in soil enzymology (Khaziev, 2005).

\section{RESULTS AND DISCUSSION}

During the experiment, the development of the oat-pea mixture was monitored, since the phytotoxic effect of HM can be established by phenotypic traits (Guseva, 2019). The observation results are presented in the table 1.

Table 1. The influence of heavy metals on the biometric characteristics of the grass mixture

\begin{tabular}{|c|c|c|c|c|c|c|c|}
\hline \multirow{3}{*}{$\begin{array}{c}\text { Experiment } \\
\text { variant }\end{array}$} & \multicolumn{3}{|c|}{ Oats } & \multicolumn{4}{|c|}{ Peas } \\
\hline & \multirow[t]{2}{*}{$\begin{array}{c}\text { Average } \\
\text { height, } \mathrm{cm}\end{array}$} & \multicolumn{2}{|c|}{$\begin{array}{c}\text { Deviations from } \\
\text { control }\end{array}$} & \multirow[t]{2}{*}{$\begin{array}{r}\text { Average } \\
\text { height, } \mathrm{cm}\end{array}$} & \multirow[t]{2}{*}{$\begin{array}{l}\text { Diameter of a sheet } \\
\text { plate, } \mathrm{cm}\end{array}$} & \multicolumn{2}{|c|}{ Deviation from control, $\%$} \\
\hline & & $\mathrm{cm}$ & $\%$ & & & Height & Diameter \\
\hline Control & $47.0 \pm 0.4$ & - & - & $53.6 \pm 0.1$ & $2.5 \pm 0.2$ & - & - \\
\hline $1(0,5$ APC $)$ & $48.4 \pm 0.3$ & +1.4 & +2.9 & $64.0 \pm 0.3$ & $2.5 \pm 0.2$ & +10.4 & +19.4 \\
\hline $2(1,5$ APC) & $46.5 \pm 0.3$ & -0.5 & -1.1 & $32.0 \pm 0.3$ & $2.0 \pm 0.3$ & -40.3 & -20.0 \\
\hline $3(4,5$ APC $)$ & $21.0 \pm 0.4$ & -26.0 & -5.3 & $28.0 \pm 0.3$ & $1.2 \pm 0.2$ & -47.8 & -52.0 \\
\hline
\end{tabular}

In the $2^{\text {nd }}$ and $3^{\text {rd }}$ variants of the experiment, the plants developed worse and were shorter than when grown on unpolluted soil. In the 1st variant, with the HM content in the soil of 0.5 APC, on the contrary, a more intensive growth and development of plants were observed in comparison with the control. Probably, the doses of HMs, primarily zinc and copper, that were introduced in the $1^{\text {st }}$ variant in an amount below the APC acted as chemical ameliorants for the Retisols depleted in microelements. The decrease in the biometric characteristics of the oat-pea grass mixture in the $2^{\text {nd }}$ and $3^{\text {rd }}$ variants occurred as a result of the phytotoxic action of HM at simulated levels of pollution. The depression of plants and the suppression of their growth is determined by the influence of to xicants on the metabolic activity and the growth rate of plant tissues, which can lead to a change in their chemical composition and a decrease in yield.

The survival functions of plants can be significantly reduced when they are grown on soil contaminated by HMs, due to the accumulation of a significant amount of pollutants by the phytomass. In order to assess the ecological purity of crop products obtained in the experiment, the content of HM in the oat-pea mixture was determined. The obtained data are presented in the $2^{\text {nd }}$ table and the $1^{\text {st }}$ and $2^{\text {nd }}$ figures.

The processing of experimental data showed that the content of HMs in vegetation directly depends on the content of pollutants in the soil, as evidenced by the values of the correlation coefficients. The quality and ecological purity of the grass mixture were assessed. 
Table 2. The content of heavy metals in oat-pea mixture $(\mathrm{mg} / \mathrm{kg})$

\begin{tabular}{|c|c|c|c|}
\hline $\begin{array}{c}\text { Variant of } \\
\text { experiment }\end{array}$ & Content of heavy metal & Deviation from control, $\mathrm{mg} / \mathrm{kg}$ & Deviation from control, $\%$ \\
\hline \multicolumn{4}{|c|}{ Copper } \\
\hline Control & $4.15 \pm 0.02$ & - & - \\
\hline $1(0,5$ APC $)$ & $7.24 \pm 0.03$ & +3.09 & +73.5 \\
\hline $2(1,5 \mathrm{APC})$ & $8.59 \pm 0.03$ & +4.44 & +106.99 \\
\hline $3(4,5$ APC $)$ & $7.71 \pm 0.02$ & +3.56 & +85.8 \\
\hline MPC $^{*}$ & 30.0 & & \\
\hline \multicolumn{4}{|c|}{ Zinc } \\
\hline Control & $37.54 \pm 0.03$ & - & - \\
\hline $1(0,5$ APC $)$ & $82.62 \pm 0.02$ & +45.08 & +120.10 \\
\hline $2(1,5 \mathrm{APC})$ & $245.20 \pm 0.03$ & +207.68 & +553.20 \\
\hline $3(4,5$ APC) & $720.20 \pm 0.02$ & +628.66 & +1818.50 \\
\hline MPC & 50.0 & & \\
\hline \multicolumn{4}{|c|}{ Lead } \\
\hline Control & $2.79 \pm 0,03$ & - & - \\
\hline $1(0,5 \mathrm{APC})$ & $2.73 \pm 0.03$ & -0.06 & -2.20 \\
\hline $2(1,5 \mathrm{APC})$ & $2.53 \pm 0.04$ & -0.26 & -9.3 \\
\hline $3(4,5$ APC $)$ & $4.50 \pm 002$ & +1.7 & +60.9 \\
\hline MPC & 5.0 & & \\
\hline \multicolumn{4}{|c|}{ Cadmium } \\
\hline Control & $0.28 \pm 0.03$ & - & - \\
\hline $1(0,5 \mathrm{APC})$ & $0.33 \pm 0.04$ & +0.05 & +17.9 \\
\hline $2(1,5$ APC) & $0.60 \pm 0.02$ & +0.32 & +114.3 \\
\hline 3 (4,5 APC) & $0.79 \pm 0.03$ & +0.51 & +182.1 \\
\hline
\end{tabular}

MPC 0.3

* MPC is the maximum permissible concentration of heavy metals for plant feed (Industry standard, 1996)

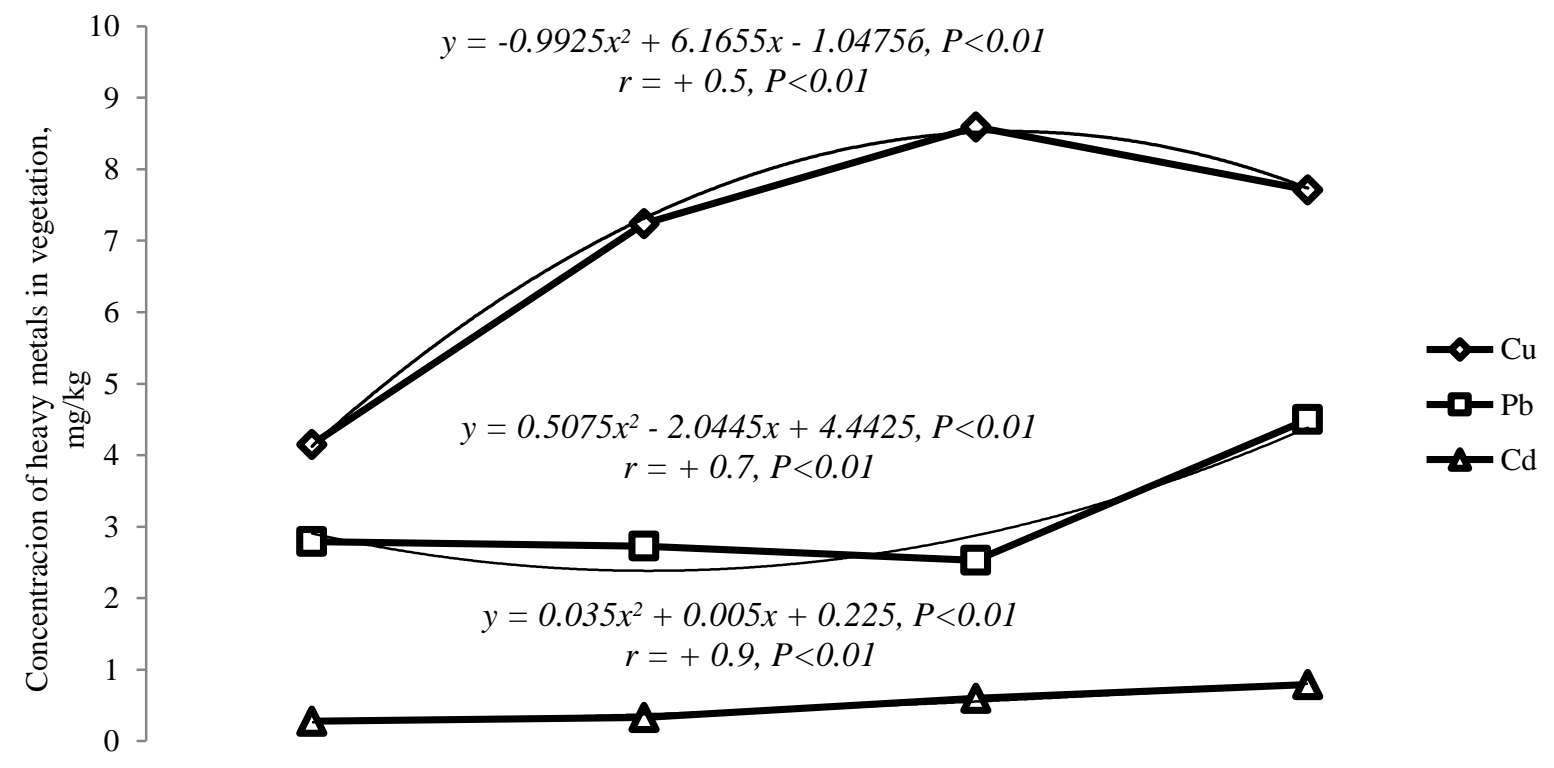

$\begin{array}{llll}\text { Control Treatment } 1 & \text { Treatment } 2 & \text { Treatment } 3\end{array}$

Figure 1. The dependence of the content of heavy metals (copper, lead, cadmium) in oat-pea mixture on the degree of soil pollution.

The content of $\mathrm{Cu}$ and $\mathrm{Pb}$ in the mixture is within the MPC values for plant feed. The concentration of $\mathrm{Cd}$ and $\mathrm{Zn}$ has already exceeded this standard in the $1^{\text {st }}$ variant of the experiment, reaching 2.6 MPC and 14.4 MPC in the $3^{\text {rd }}$ variant, respectively. Of the studied HMs, only the concentration of zinc has exceeded the phytotoxic one $(400 \mathrm{mg} / \mathrm{kg}) \mathrm{by} 1.8$ times (variant 3). For almost all 4 elements, there was a tendency to an increase in their content in the phytomass as the degree of soil pollution increased. Thus, the ecological quality of vegetation already in the $1^{\text {st }}$ variant of the experiment does not correspond to the standards for $\mathrm{Zn}$ and $\mathrm{Cd}$. The obtained data about the accumulation of toxicants in the 
phytomass allow us to conclude about the translocation ability of HM in Retisols: copper and lead pass from soil to plants very weakly, zinc and cadmium have significant mobility, even at their concentration in the soil of 0.5 APC.
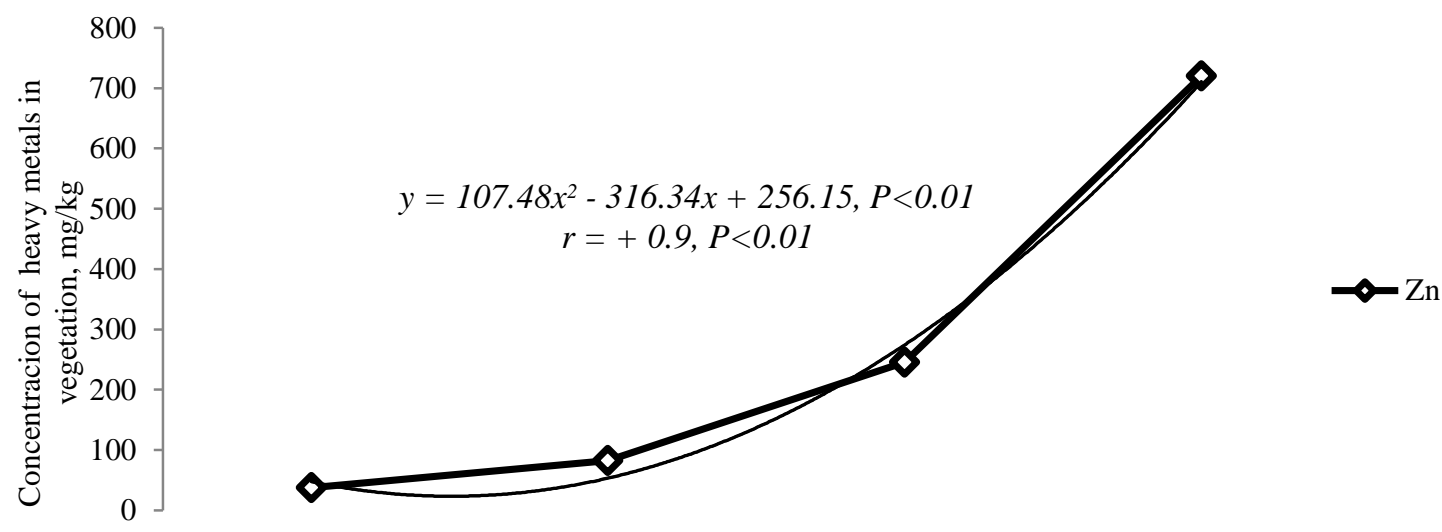

Control

Treatment 1

Treatment 2

Treatment 3

Figure 2. The dependence of zinc content in oat-pea mixture on the degree of soil pollution

In the experiment, under conditions of increased HM content, a decrease in the turgor of plant tissues was observed that is due to the loss of elasticity of the cell walls, possibly caused by the partial replacement of calcium by metal ions and a change in membrane permeability. A decrease in the size of the root system was also recorded, that reduced the area of the root suction surface and, as a consequence, the water content in plant cells.

Pea leaves in the experiment, especially in the $3^{\text {rd }}$ variant, lost their natural color. The reason for this phenomenon is a decrease in the content of green pigments in the presence of HM and suppression of chlorophyll biosynthesis, which is associated with the direct effect of toxicants on the activity of biosynthetic enzymes, as well as the displacement of the magnesium ion from the chlorophyll molecule by metal ions.

The research has shown that heavy metals under experimental conditions generally suppressed the biochemical activity of Retisols, but their inhibitory effect was manifested to varying degrees in relation to individual enzymatic reactions (Table 3, Figure 3).

Table 3. Activity of enzymes in Retisols

\begin{tabular}{|l|c|c|c|}
\hline \multirow{2}{*}{ Experiment variant } & \multicolumn{3}{|c|}{ Enzymes } \\
\cline { 2 - 4 } & $\begin{array}{c}\text { Invertase, } \\
\mathrm{mg} \text {-glucose / g- soil }\end{array}$ & $\begin{array}{c}\text { Urease, } \\
\mathrm{mg} \mathrm{NH} 4 / 10 \mathrm{~g} \text { - soil }\end{array}$ & $\mathrm{Phosphatase,} 2 \mathrm{O5} / 10 \mathrm{~g}$ - soil \\
\hline Control & $6.5 \pm 0.4$ & $28.6 \pm 2.1$ & $5.1 \pm 0.3$ \\
\hline $1(0,5$ APC) & $6.9 \pm 0.5$ & $29.1 \pm 1.9$ & $5.2 \pm 0.2$ \\
\hline $2(1,5$ APC $)$ & $5.8 \pm 0.2$ & $18.2 \pm 2.0$ & $4.3 \pm 0.4$ \\
\hline $3(4,5$ APC $)$ & $5.1 \pm 0.4$ & $16.6 \pm 1.7$ & $2.8 \pm 0.3$ \\
\hline
\end{tabular}

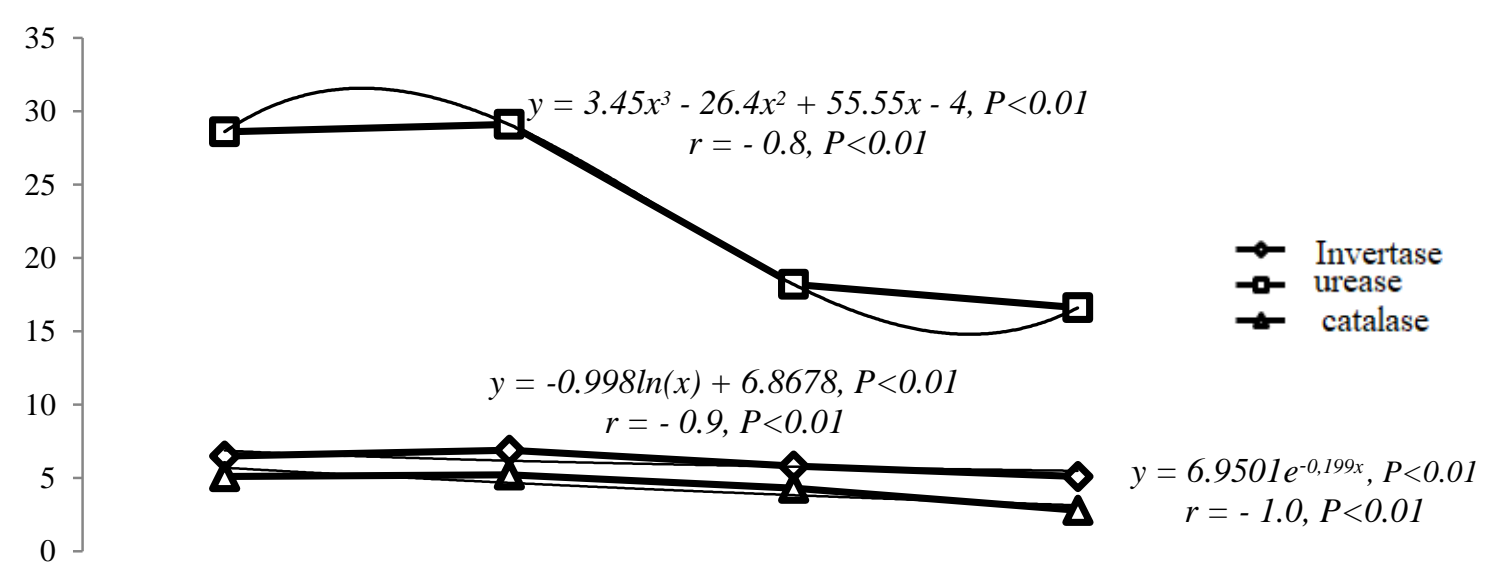

$\begin{array}{llll}\text { Control Treatment } 1 & \text { Treatment } 2 & \text { Treatment } 3\end{array}$

Y-axis value: indicators of activity of invertase, urease, and catalase enzymes

Figure 3. Biochemical activity of Retisols in the experiment. 
The combined effect of HMs at their concentrations in the soil exceeding the standard values clearly negatively affects the activity of hydrolytic enzymes. In the $1^{\text {st }}$ variant, there was a slight increase in their activity. But with an increase in the content of toxicants, due to the disruption of the functioning of the soil microbiome, the activity of enzymes decreased in the $2^{\text {nd }}$ option for invertase, urease and phosphatase by $11 \%, 36 \%$ and $16 \%$ respectively, for the $3^{\text {rd }}$ option these indicators were $22 \%, 42 \%$ and $45 \%$.

\section{CONCLUSIONS}

In the variant of the experiment with a content of heavy metals of 0.5 APC in the soil, the studied elements, mainly zinc and copper, act as chemical ameliorants for Retisols depleted in microelements. The complex effect of heavy metals $(\mathrm{Cu}, \mathrm{Zn}, \mathrm{Pb}, \mathrm{Cd})$ at doses of 1.5 and 4.5 APC is phytotoxic, which negatively affects the biometric parameters of the cereal-legume mixture, and also leads to the accumulation in biomass in quantities exceeding the permissible standards.

The combined effect of HM leads to a synergistic effect, which is expressed in the suppression of the functioning of the microbiome in Retisol and a decrease in the activity of hydrolytic enzymes.

\section{REFERENCES}

1. Ananyeva Yu.S., Shpis T.E. 2010. Influence of lead pollution on the biological properties of leached chernozem. Bulletin of Altai State Agrarian University, Vol. 10 (72), pp. 29-32. (in Russian).

2. Evdokimova O.V., Guseva T.M., Kanina I.V. 2017. Microorganisms - biological indicators of the safety of environmental objects. Scientific life, Vol. 11, pp. 120-127. (in Russian).

3. Evdokimova G.A. 2014. Soil microbiota as a factor of soil resistance to pollution. Theoretical and applied ecology, Vol. 2, pp. 17-24. (in Russian).

4. Fokina A.I., Ashikhmina T.Ya., Domracheva L.I., Gornostaeva E.A., Ogorodnikova S.Yu. 2015 Heavy metals as a factor in metabolic alteration in microorganisms (review). Theoretical and applied ecology, Vol. 2, pp. 5-18. (in Russian).

5. GN 2.1.7.2042-06. Approximately permissible concentrations (APC) of chemicals in soil. Hygienic Standards. 2006. Federal Center for Hygiene and Epidemiology of Rospotrebnadzor. Moscow. (in Russian).

6. Guseva T.M. Assessment of the effect of heavy metals on biometric indicators of plants. 2019. Innovative scientific research in the modern world: theory, methodology, practice, pp. 16. (in Russian).

7. Industry standard 10 125-96. 1996. Vegetable and compound feed. Methods for the determination of heavy metals. Moscow. (in Russian).

8. Khaziev F.H. 2005. Methods of soil enzymology. Nauka, Moscow. (in Russian).

9. Korotchenko I.S. 2011. Phytotoxicity and enzymatic activity of leached chernozem under heavy metal pollution. Bulletin of Krasnoyarsk State Agrarian University, Vol. 5, pp. 109-115. (in Russian).

10. Kurakov A.V., Zvyagintsev D.G., Philip Z. 2000. Changes in the complex of heterotrophic microorganisms under the contamination of sod-podzolic soil by lead. Soil science, Vol. 12, pp. 1448-1456. (in Russian).

11. Mazhaisky Yu A, Zhelyazko V I 2003 Ecological aspects of land reclamation in the south of the Nonblack Soil Zone (Moscow: Publishing House of the Moscow State University). (in Russian).

12. Mazhaisky Yu.A., Evtyukhin V.F. 2014 Influence of heavy metal pollution of soil on its properties and environmental indicators. Materials of the annual session of the Scientific Council of the Russian Academy of Sciences about the problems of geoecology. Vol. 16, pp. 438-442. (in Russian).

13. Methodical instructions 2.1.7.730-99. Hygienic assessment of soil quality of settlements.1999. Standards publishing, Moscow. (in Russian).

14. Neutralization of contaminated soil. 2008. under the Yu A Mazhaisky's general ed. Meshchersky Branch of all-Russian research institute of hydraulic engineering and land reclamation n. A.N. Kostyakova, Ryazan. (in Russian).

15. Skugoreva S.G., Fokina A.I., Domracheva L.I. 2016 Toxicity of heavy metals for barley plants, soil and rhizosphere microflora. Theoretical and applied ecology, Vol. 2, pp. 32-45. (in Russian). 